\title{
MMP1 wt Allele
}

National Cancer Institute

\section{Source}

National Cancer Institute. MMP1 wt Allele. NCI Thesaurus. Code C49731.

Human MMP1 wild-type allele is located in the vicinity of $11 \mathrm{q} 22.3$ and is approximately 8 $\mathrm{kb}$ in length. This allele, which encodes interstitial collag enase protein, is involved in the breakdown of the extracellular matrix via the degradation of interstitial collagens (types I, II and III). The MMP1 gene is associated with neoplasm invasiveness. 